\title{
Pengembangan Wanawisata Berbasis Apikultur Melalui Kuliah Kerja Nyata Tematik di Desa Darmakradenan Kecamatan Ajibarang Kabupaten Banyumas
}

\author{
Okti Herliana $^{*}$, AH Syaeful Anwar², Ahmad Fauzi ${ }^{3}$ \\ ${ }^{1,2,3}$ Laboratorium Agroekologi, Fakultas Pertanian, Universitas Jenderal \\ Soedirman \\ *koresponden author: $\underline{\text { o.herliana@gmail.com }}$
}

\begin{abstract}
ABSTRAK
Desa Darmakradenan merupakan salah satu desa di wilayah hutan dengan produktifitas petani yang masih rendah disebabkan kepemilikan lahan sempit, jenis usaha tani kurang beragam, kurang teroganisasi dan lemahnya regenerasi. Pengelolaan lahan di kawasan hutan memerlukan teknologi yang tepat guna dengan pendekatan sosio-ekologis agar dapat mensejahterakan petani sekaligus tidak merusak fungsi hutan. Penerapan agroforestry berbasis apiculture merupakan salah satu stategi pengelolaan kawasan hutan secara berkelanjutan sebagaimana telah dilakukan oleh sebagian petani Desa Darmakradenan. Selain manfaat secara ekonomi, integrasi agroforestri dengan budidaya lebah juga bermanfaat secara ekologi mengingat peran lebah sebagai polinator. Kegiatan KKN tematik ini bertujuan untuk meningkatkan ketrampilan dan kemandirian masyarakat Desa Darmakradenan dalam mengelola kawasan hutan dengan menerapkan agroforestry berbasis apiculture dan secara profesional mengembangkannya menjadi komoditas pariwisata. Pendampingan masyarakat difokuskan pada bidang konservasi dan pengelolaan hutan, budidaya dan diversifikasi produk madu, keorganisasian petani kawasan hutan, dan pengembangan wisata. Metode yang dilakukan adalah PRA (Partisipatory Rural Appraisal) yaitu peran aktif pihak yang terlibat yaitu mahasiswa peserta KKN, masyarakat Desa Darmakradenan dan Kelompok Tani Hutan Darma Jaya. Hasil kegiatan menunjukkan terdapat peningkatan jumlah petani yang tergabung dalam kelompok, peningkatan pemahaman petani tentang arti penting konservasi hutan, keterampilan budidaya tanaman buah sebaga upaya konservasi lahan, keterampilan membuat produk olahan dari madu, pengelolaan administsasi kelompok tani, dan terjadi koordinasi antar stakeholder untuk pengembangan pariwisata yang menghasilkan rekomendasi arah pengembangan pariwisata desa sebagai dasar pemerintah desa menyusun rencana pembangunan.
\end{abstract}

Kata Kunci: Apikulture, agroforestri, kelompok tani hutan, KKN.

\section{ABSTRACT}

Darmakradenan Village is one of the villages in the forest area with low farmer productivity due to narrow land ownership, less diverse types of farming, less organized and weak regeneration. Land management in forest areas requires appropriate technology with a socio-ecological approach in order to make farmers prosperous while not destroying forest functions. The application of apiculture-based agroforestry is one of the strategies for sustainable forest area management as has been done by some Darmnakradenan village farmers. Apart from economic benefits, the integration of agroforestry with bee cultivation is also ecologically beneficial considering the role of bees as pollinators. This thematic KKN activity aims to improve the skills and independence of the Darmakradenan village community in managing forest areas by applying apiculture-based agroforestry and professionally developing it into a tourism commodity. Community assistance is focused on the areas of forest conservation and management, cultivation and diversification of honey products, forest area farmer organizations, and tourism development. The method used is PRA (Participatory Rural Appraisal), namely the active role of the parties involved, namely students participating in KKN, Darmakradenan village communities and Darma Jaya Forest Farmers Group. The results of the activity show that there is an increase in the number of farmers who are members of the group, an increase in farmers' understanding of the importance of forest conservation, skills in cultivating fruit trees as an effort to conserve land, skills in making processed products from honey, management of farmer group administration, and coordination between stakeholders for tourism development. which produces recommendations for the direction of village tourism development as the basis for the village government to prepare development plans.

Keywords: Apiculture, agroforestry, forest farmer community, KKN, 


\section{PENDAHULUAN}

Desa Darmakradenan berada di wilayah Kecamatan Ajibarang Kabupaten Banyumas. Luas wilayah Desa Darmakradenan adalah 1.184.245 ha dengan konfigurasi berupa pegunungan dengan ketinggian antara $250-750 \mathrm{~m}$ di atas permukaan laut (dpl), sehingga tergolong daratan sedang dan sebagian pada dataran tinggi. Sebagian tanahnya berupa tanah berbatuan, tanah sawah, dan tanah darat. Sawah irigasi semi teknis di Desa Darmakradenan seluas 53,289 ha, sawah tadah hujan seluas 53,315 ha dan tegal/ladang seluas 74,58 ha. Tanah perkebunan milik negara seluas 197,400 ha dan tanah perkebunan swasta seluas 227,650 ha. Tanah fasilitas umum yang merupakan kas desa seluas 24,86 ha, lapangan seluas 7 ha, perkantoran pemerintahan seluas 516 ha dan lainnya seluas 3,766 ha.

Sebagian besar potensi lahan di Desa Darmakradenan adalah lahan kering dan perkebunan dengan topografi berbukit. Kondisi lahan yang seperti ini tidak memiliki banyak opsi penggunaannya dibatasi oleh kesuburan dan kaidah konservasi. Tanah di Desa Darmakradenan sebagian besar berbatu dengan tingkat kesuburan rendah, sehingga umumnya ditanami tanaman kayu dan perkebunan. Lahan sawah yang ada lebih banyak yang tadah hujan sehingga produktivitasnya rendah dan kurang memberikan nilai tambah pada kesejahteraan petani di Desa Darmakradenan.

Kondisi geograsfis dan sosial semacam ini umum dijumpai pada masyarakat di sekitar hutan atau perkebunan. Oleh karena itu diperlukan upaya intensifikasi pengelolaan lahan untuk mendapatkan nilai tambah secara ekonomi bagi masyarakat. Salah satu strategi yang dapat ditempuh adalah melalui pendekatan agroforestry, yaitu penggabungan pengelolaan lahan untuk tanaman kayu/perkebunan dengan tanaman pangan maupun ternak. Sebagian besar penduduk mata pencaharian pokoknya sebagai petani, sedangkan yang lainnya sebagai buruh tani, wiraswasta, pengusaha, pengrajin, pedagang, PNS, TNI/Polri, penjahit, sopir, karyawan swasta, tukang kayu, tukang batu, guru swasta dan montir. Tercatat dari 2.535 Kepala Keluarga, 1.813 diantaranya adalah rumah tangga petani. Sebagian besar keluarga petani memiliki lahan di bawah 1 ha, sehingga cukup wajar jika dilihat dari aspek kesejahteraan penduduknya Desa Darmakradenan masih memiliki 882 keluarga pra sejahtera (Dinkominfo Kab. Banyumas, 2017).

Berangkat dari kondisi tersebut beberapa pemuda membentuk kelompok tani hutan yang memiliki kegiatan budidaya lebah, perkebunan dan pengelolaan hutan. Kelompok tani yang bernama Kelompok Tani Hutan Darma Jaya ini beranggota 25 orang pemuda dari seluruh wilayah Desa Darmakradenan. Kelompok tani ini bermula dari salah satu pendirinya yang melihat potensi desanya banyak ditemukan sarang lebah liar di kawasan hutan dan kemudian dipelajari untuk bisa didomestikasi sehingga mengahasilkan madu. Domestikasi lebah ini pada akhirnya menghasilkan madu yang dapat menambah penghasilan. Keberhasilan ini kemudian ditularkan kepada pemuda-pemuda desa untuk dapat belajar membudidayakan lebah di rumah masing-masing. Di Desa Darmakradenan juga terdapat beberapa Goa alami yang secara estetis dapat mendukung kegiatan pariwisata, akan tetapi belum dikelola dengan baik. Kegiatan budidaya lebah dan wanawisata jelajah Goa menjadi satu potensi yang dapat meningkatkan pendapatan dan kesejahteraan masyarakat

Menurut (Salmah, 1992) budidaya lebah madu telah lama menjadi bagian dari kehidupan masyarakat Indonesia, khususnya yang tinggal di pedesaan dan sekitar hutan. Mereka mengenal dengan baik tradisi budidaya lebah madu, khususnya jenis lokal Apis cerana, meskipun dalam bentuk dan teknik sederhana. Tingginya minat peternak atau calon peternak daerah lain seperti calon peternak di Kecamatan Cilongok dan 
Okti Herliana, AH Syaeful Anwar, Ahmad Fauzi - Pengembangan Wanawisata Berbasis Apikultur Melalui Kuliah Kerja Nyata Tematik di Desa Darmakradenan Kecamatan Ajibarang Kabupaten Banyumas

Kecamatan Pekuncen menjadikan kelompok tani hutan Darma Jaya sebagai referensi dan pusat pelatihan budidaya lebah. Hal ini merupakan nilai tambah selain berkepentingan secara ekonomi, kegiatan kelompok ini juga bernilai edukasi. Kondisi yang demikian sangat potensial untuk dikembangkan ke ranah pariwisata pertanian terpadu budidaya lebah dan tanaman buah (Murtidjo, 1998)

$$
\text { Kuliah Kerja Nyata (KKN) }
$$

merupakan salah satu bentuk praktek penerapan ilmu yang diperoleh selama perkuliahan untuk diintroduksikan pada masyarakat dalam rangka memberikan solusi permasalahan yang dihadapi oleh masyarakat desa. Melalui kegiatan KKN Tematik diharapkan peran Perguruan Tinggi dalam mendampingi Kelompok Tani yang sedang berkembang ini untuk lebih mandiri dan terampil dalam melaksanakan kegiatannya yaitu pengelolaan hutan secara berkelanjutan melalui budidaya lebah (apiculture). Sumbangan ide dan pemikiran dari berbagai disiplin ilmu sangat diperlukan untuk membawa kelompok tani tersebut ke ranah pariwisata sehingga mampu meningkatkan perekonomian masyarakat Desa Darmakradenan dan membawa manfaat yang lebih besar kepada masyarakat umum.

Melihat potensi alam dan sumberdaya manusia yang ada maka diperlukan upaya untuk memecahkan masalah kesejahteraan dan pengembangan potensi Desa Darmakradenan sebagai Desa Agrowisata berbasis agroforestry dan apiculture mengingat potensi pasar dari pengembangan lebah madu sangat besar (Kuntadi, 2003). Visi pengembangan agrowisata berbasis apiculture ditetapkan sesuai dengan gambaran impian luhur dan pencapaian tujuan lembaga dalam kurun waktu satu periode kepengurusan yang memuat filosofi dalam pelaksanaan kerja kepariwisataan berbasis masyarakat di wilayah Kecamatan Ajibarang. Adapun visi yang dicanangkan dalam waktu 12 (dua belas) tahun mulai dari tahun 2011-2023 adalah "Membangun
Pariwisata yang unggul dan bermartabat bagi kesejahteraan rakyat".

Tujuan dari program KKN bertema pengembangan agroforestry berbasis apiculture ini antara lain: 1). Menerapkan konsep pengelolaan lahan pertanian secara berkelanjutan melalui konsep agroforestry yang dipadukan dengan budidaya lebah (apiculture) pada KTH Darma Jaya Desa Darmakradenan. 2). Membantu memecahkan permasalahan terkait rendahnya produktivitas lahan di wilayah $\mathrm{KTH}$ Darma Jaya Desa Darmakradenan dan potensi kerusakan lahan hutan dan perkebunan sebagai daerah resapan air. 3) Mengembangkan agroforestry berbasis apiculture di KTH Darma Jaya menjadi eduwisata dan pusat pelatihan. 4). Meningkatkan kemandirian dan keterampilan KTH Darma Jaya Desa Darmakradenan dalam menjalankan usaha budidaya lebah, dan produk olahan berbahan madu.

\section{METODE}

a. Tempat dan Waktu

Program KKN Tematik ini dilaksanakan di Desa Darmakradenan Kecamatan Ajibarang Kabupaten Banyumas mulai Bulan Juli sampai dengan Agustus 2019.

b. Khalayak Sasaran Strategis

Program KKN Tematik ini melibatkan 24 mahasiswa dari berbagai macam disiplin ilmu, Kelompok Tani Hutan Darma Jayaibu-ibu PKK, siswa sekolah dan masyarakat Desa Darmakradenan yang bermukim di sekitar hutan atau perkebunan dengan jenis usaha adalah petani dengan memanfatkan tegakan tanaman tahunan milik Perhutani dan pembudidaya lebah untuk menghasilkan madu

c. Metode Kegiatan

Kegiatan KKN Tematik ini dilaksanakan melalui tiga tahapan, yaitu: Persiapan dan Pembekalan. Pelaksanaan kegiatan dan evaluasi untuk menentukan arah keberlanjutan program. Metode yang digunakan dalam pelaksanaan kegiatan KKN Tematik ini adalah Partisipatory 
Rural Appraisal (PRA). Yaitu keterlibatan secara aktif seluruh peserta yang terlibat dalam kegiatan. Mahasiswa beserta dengan Dosen Pembimbing Lapangan memberikan penyuluhan terkait budidaya lebah, budidaya tanaman sumber pakan lebah dan mendampingi pembuatan demplot. Mahasiswa dan anggota kelompok tani hutan melakukan sosialisasi budidaya lebah kepada anggota kelompok baru, memberikan edukasi kepada siswa sekolah dan masyarakat terkait manfaat madu dan memberikan pelatihan pembuatan makanan ringan berbahan madu pada akhir kegiatan dilaksanakan evaluasi. Obyek utama kegiatan adalah kegiatan budidaya lebah oleh anggota kelompok tani hutan, konservasi lahan dengan sistem agroforestry untuk dikembangkan sebagai wanawisata.

d. Indikator Keberhasilan

Indikator kebrhasilan kegiatan KKN ini adalah terdapat penambahan jumlah anggota kelompok tani hutan Darmajaya, Peningkatan jumlah koloni lebah, peningkatan pemahaman dan ketrampilan anggota kelompok dalam budidaya lebah dalam pembuatan stek dan penanaman tanaman bunga dan buah sumber pakan lebah, perluasan area wanawisata berbasis apikutur

e. Metode Evaluasi

Metode evaluasi yang digunakan adalah dengan mengadakan pree test dan post test untuk mengukur tingkat keberahasilan sosialisasi dan pelatihan yang sudah diberikan terhadap kelompok sasaran

\section{HASIL DAN PEMBAHASAN}

Kegiatan Kuliah Kerja Nyata (KKN) dilaksanakan selama 35 hari mulai tanggal 17 Juli sampai dengan 23 Agustus 2019. Mahasiswa yang terlibat dalam kegiatan ini terdiri dari berbagai disiplin ilmu yang terkait. Bidang Lingkungan hidup terkait konservasi lahan, pembibitan dan penanaman di lokasi wanawisata dilaksanakan dan pemetaan potensi goa untuk mendukung wanawisata dilaksanakan oleh mahasiswa pertanian dan teknik geologi, budidaya lebah didampingi oleh mahasiswa dari fakutas peternakan. Bidang pendidikan terkait sosialisasi manfaat lebah dan madu untuk kesehatan dan promosi eduwisata berbasis budidaya lebah dilaksanakan oleh mahasiswa dari prodi biologi, ilmu hukum dan ilmu komunikasi. Bidang ekonomi terkait penguatan kelompok, manajemen usaha dan perluasan pemasaran dilaksanakan oleh mahasiswa dari jurusan ekonomi. Bidang kesehatan terkait kandungan gizi dan manfaat mengkonsumsi madu serta produk olahannya didampingi oleh mahasiswa dari ilmu-ilmu kesehatan.

a. Konservasi Lahan

Sebagian lahan pertanian Desa Darmakradenan dekat dengan area hutan milik Perhutani. Topografi tanah berlereng memerlukan upaya konservasi agar untuk menjaga kondisi lingkungan agar tidak rawan longsor. Selain itu kegiatan agroforestry juga dimaksudkan untuk menyediakan pakan lebah. Jenis tanaman yang ditanam pada lahan berlereng adalah tanaman putsa (Zizipus mauritiana), jambu kristal (Psidium guava) Buah Tin (Ficus carica) dan Srikaya (Annona Squamosa). Jenis buah tersebut bunganya menjadi salah satu sumber pakan lebah dan secara ekonomis mempunyai nilai tambah yang dapat meningkatkan pendapatan petani.

Makanan pokok lebah yaitu serbuksari (pollen) dan nektar (larutan gula yang berasal dari tanaman). Bagi lebah, serbuksari adalah sumber protein, sementara nektar adalah sumber karbohidrat. Kedua jenis makanan ini diambil oleh lebah dari tanaman, khususnya di bagian bunga. Namun, pada tanaman tertentu, misalnya karet (Ficus elastica) dan akasia (Acacia spp), nektar tidak dikeluarkan dari kelenjar yang ada di bagian dasar bunga, melainkan dari tunas daun muda dan pangkal daun. Selain itu, lebah madu juga dapat memperoleh karbohidrat dari honeydew, yaitu cairan gula yang disekresikan tanaman melalui perantaraan sejenis kutu (plant sucking insects). (Kuntadi, 2001) 
Okti Herliana, AH Syaeful Anwar, Ahmad Fauzi - Pengembangan Wanawisata Berbasis Apikultur Melalui Kuliah Kerja Nyata Tematik di Desa Darmakradenan Kecamatan Ajibarang Kabupaten Banyumas

Dalam kegiatan ini mahasiswa

KKN bersama dengan anggota KTH Darma Jaya melakukan penanaman tanaman buah sebagai upaya konservasi, Mahasiswa dan Dosen pembimbing memberikan pelatihan pembuatan stek dan cangkok tanaman buah, pelatihan pembuatan Pupuk Oganik Cair (POC) dari pelepah pisang molase dan bakteri dekomposer. Bahan-bahan tersebut di rendam selama 14 hari, POC digunakan sebagai pupuk guna memberikan nutrisi pada tanaman stek. Mahasiswa juga mendampingi pembuatan 1000 bibit tanaman tin dan bunga untuk supply makanan lebah, pembersihan area dekat hutan sebagai obyek wanawisata dan penanaman pada lahan dengan kemiringan $30^{\circ}$ sebagai upaya konservasi lahan. Kegiatan diawali dengan sosialisasi pembuatan stek dan POC dilanjutkan dengan pelatihan dan pembuatan demplot. Kelompok sasaran kegiatan ini adalah kelompok tani hutan Darmajaya.

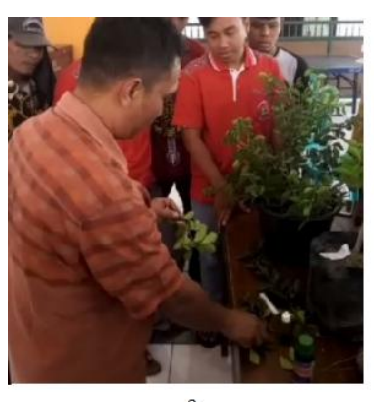

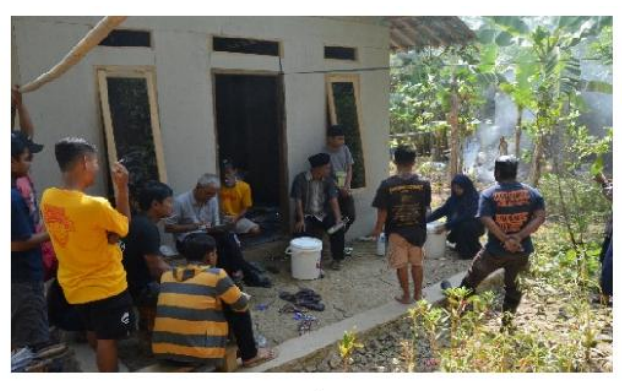

b

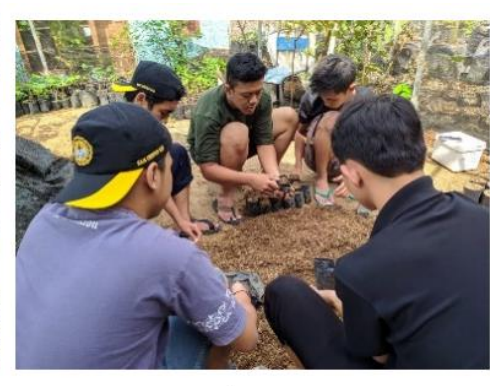

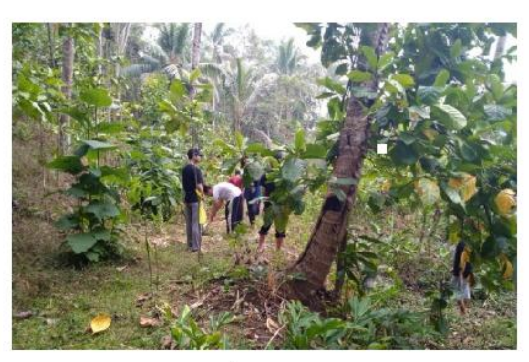

d

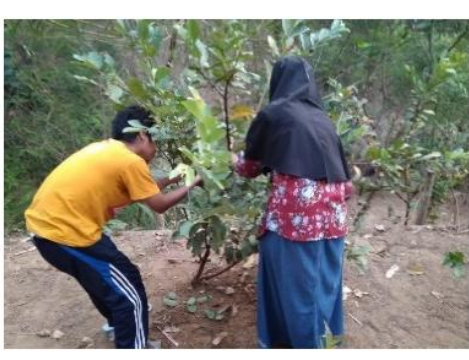

Ket. a. Sosialisasi dan pelatihan pembuatan stek tanaman buah

b. Sosialisasi dan pelatihan pembuatan pupuk organik cair

c. Pengisian media tanam untuk pembibitan tanaman buah

d. Pembersihan lahan untuk area wana wisata

e. Penanaman dan pemeliharaan tanaman buah.

\section{b. Budidaya Lebah Madu}

Kelompok Tani Hutan Darma Jaya bergerak di bidang usaha budidaya lebah madu jenis Aphis cerana dan Trigona. Madu yang di produksi dijual kepada CV Prawita Garden yang sudah bergerak lebih dahulu di bidang budidaya dan penjualan madu dengan merk Madu Raja Tawon. Pemasaran produk ini meliputi daerah Banyumas raya dan memenuhi permintaan kalangan terbatas pada penjualan online. Kehadiran mahasiswa KKN memberi motivasi agar lebih banyak masyarakat yang bergabung menjadi anggota kelompok tani hutan
Darma Jaya, sehinga jumlah peternak, koloni lebah dan produksi lebah dapat ditingkatkan. Pendampingan yang dilakukan oleh mahasiswa KKN mampu menarik minat masyarakat untuk bergabung menjadi anggta kelompok tani hutan peternak lebah semula 25 menjadi 35 orang.

Kegiatan budidaya lebah dimulai dari menangkap koloni lebah dari hutan, atap rumah, atau tempat lain. Kemudian Memasang stup/glodok kosong di tempat-tempat tertentu dengan harapan akan didatangi lebah (memancing). kemudiaan menempatkan stup/kotak 
pemeliharaan Stup (koloni lebah) ditempatkan dekat dengan jalan pemeriksa dan jauh dari keramaian terlindung dari terik matahari dan curahan langsung air hujan. Kotak diletakkan di atas standar dengan tinggi \pm 0,5 $\mathrm{m}$ di atas permukaan tanah, dan kaki standar diolesi minyak/oli agar semut dan serangga lain tidak naik. Posisi kotak menghadap matahari terbit dan membelakangi jalan pemeriksaan. Setelah sekitar 3 bulan saatnya mulai memanen madu. Dengan tahapan membuka kotak eram dan mengangkat sisiran madu. Memeriksa sisiran madu, ambil sisiran yang telah berisi madu dan tertutup lilin, bila sisiran belum menggunakan pondasi sarang, maka madu dilakukan pemotongan sebatas sisiran yang berisi. Masukan kembali sisiran berisi anakan ke dalam sarang, melakukan pemerasan dengan menggunakan kain kasa dan penjepit kayu, menyaring sebanyak 2 kali madu hasil perasan, dengan menggunakan kain kasa. Madu segera disimpan dalam wadah, dan tutup yang rapat. Usaha lebah madu memiliki peranan penting di dalam strategi pembangunan ekonomi masyarakat pedesaan dan sektor pertanian berkelanjutan. Kegiatan usaha lebah madu menghasilkan produk pangan berkualitas yang dapat membantu meningkatkan gizi dan penghasilan masyarakat pedesaan. Melalui fungsi polinasi, lebah madu juga berperan besar dalam meningkatkan produksi buah dan biji serta menjaga kelangsungan hidup dan karagaman jenis tumbuhan. Di banyak negara, budidaya lebah madu telah berkembang menjadi kegiatan usaha berskala besar. Hasil yang diperoleh dari industri perlebahan tidak saja terbatas pada madu saja, tetapi juga termasuk lilin, royal jelly, propolis, tepungsari, dan racun lebah. Selain itu, tambahan penghasilan dapat diperoleh dari jasa sewa koloni untuk penyerbukan tanaman pertanian (Lamusa 2010)

Budidaya lebah madu adalah salah satu kegiatan usaha yang tidak berbasis lahan, sehingga tidak menjadi pesaing bagi usaha pertanian pada umumnya. Perlebahan bahkan berperan dalam optimalisasi sumber daya alam melalui pemanfaatan nektar dan serbuksari, yakni dua produk tumbuhan yang sebagian besar akan terbuang sia-sia apabila tidak dimanfaatkan untuk pakan lebah madu. Dengan begitu, perlebahan merupakan jenis kegiatan yang dapat memberikan nilai tambah terhadap budidaya tanaman (Minarti, 2010)

Pengembangan perlebahan dinilai penting mengingat Indonesia memiliki potensi yang sangat besar di bidang ini. Keadaan alam dan kondisi iklim Indonesia sangat mendukung untuk usaha budidaya lebah, seperti tersedianya sumber pakan (bee forage) sepanjang tahun dan aneka jenis lebah madu; selain itu, masyarakat, secara tradisional, sudah mengenal budidaya lebah. Usaha budidaya lebah madu sudah lama dikenal oleh masyarakat pedesaan maupun masyarakat sekitar hutan dan Kondisi alam Indonesia yang subur memungkinkan tumbuhnya berbagai jenis tanaman. Masyarakat mengenal dengan baik madu yang dihasilkan dari budidaya lebah madu khususnya jenis lokal Apis cerana (Saepudin, 2013). 
Okti Herliana, AH Syaeful Anwar, Ahmad Fauzi - Pengembangan Wanawisata Berbasis Apikultur Melalui Kuliah Kerja Nyata Tematik di Desa Darmakradenan Kecamatan Ajibarang Kabupaten Banyumas

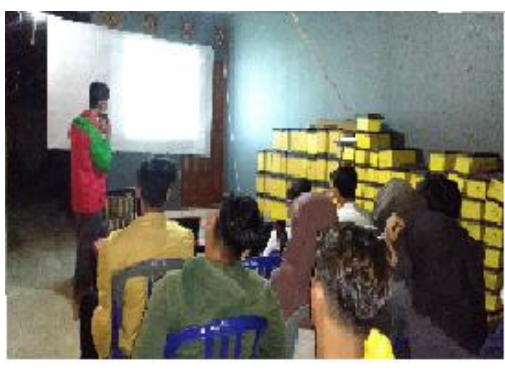

f

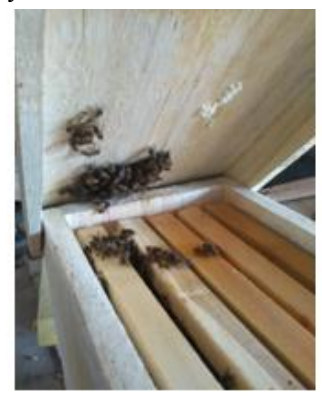

g

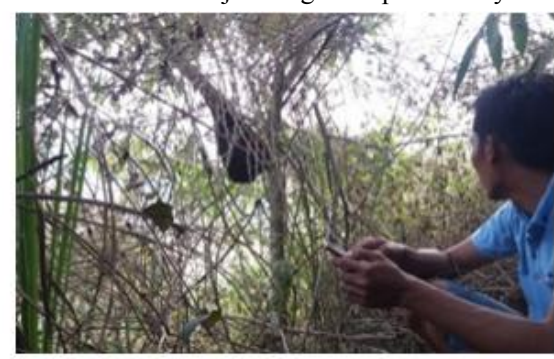

$\mathrm{h}$

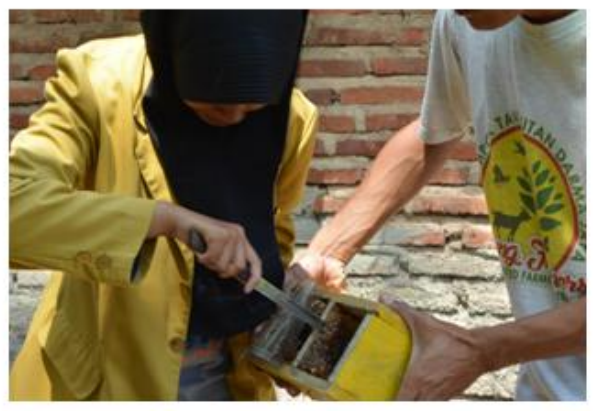

i

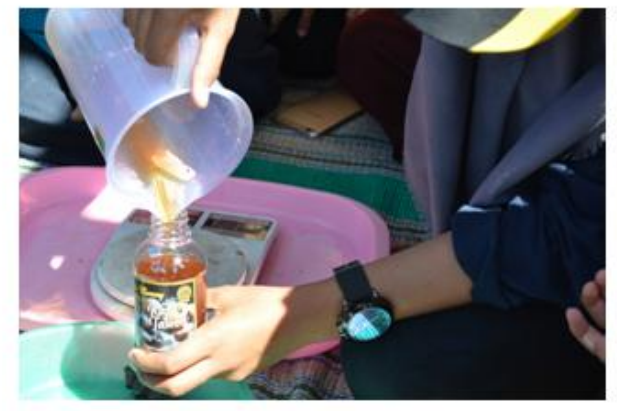

j

Gambar f. Sosialisasi budidaya lebah madu pada anggota baru kelompok tani g,h,I,k proses budidaya lebah sampai dengan pemanenan madu.

c. Pemetaan Potensi Desa untuk Wanawisata

Peningkatan pendapatan petani dapat ditingkatkan secara nyata apabila petani tidak saja menjual produk madunya tapi juga menjual proses dan tempat budidaya lebahnya sebagai tempat wisata, mengingat saat ini pariwisata sudah seakan menjadi kebutuhan pokok bagi masyarakat. Wisata ini nanti bisa diintegrasikan dengan potensi lain yang ada di desa ini semisal goa kapur yang menurut informasi warga ada banyak di Desa Darmakradenan. Tumbuhnya pariwisata di desa ini akan memuculkan multiplayer effect sehingga akan mengangkat perekonomian masyarakat desa secara umum, tentunya dengan perencanaan yang matang dengan dukungan semua pihak khususnya masyarakat. Oleh karena itu, salah satu agenda KKN adalah melaksanakan FGD (Focus Group Discussion) yang mempertemukan beberapa komponen masyarakat yang meliputi Pemerintahan Desa, Dinas Pemuda Olahraga Budaya dan Pariwisata (Dinporabudpar), Dinas
Sosial Pemberdayaan Masyarakat Desa (Dinsospermades), Bintara Pembina Desa (Babinsa), Bintara Pembina Keamanan Ketertiban Masyarakat (Babinkamtibmas), Rukun Warga (RW), Kelompok Tani Hutan (KTH) Darma Jaya, Pemuda Sadar Wisata (Pokdarwis), Bank Sampah, Taman Baca Masyarakat (TBM) dan Paguyuban Pemuda Pelopor dan Karangtaruna. Melalui FGD ini telah dicapai kesepakatan bersama untuk mengembangkan pariwisata di Desa Darmakradenan dengan mengoptimalkan semua potensi yang adaa seperti kehutanan, budidaya lebah dan situs goa kapur yang banyak terdapat di Desa Darmakradenan. Imam WS selaku kepala Desa Darmakradenan mengapresiasi kegiatan FGD KKN Unsoed ini. Menurut kepala desa, forum ini merupakan momentum yang baik untuk menggali aspirasi masyarakat terkait arah pembangunan desa yang akan segera kami tindaklanjuti sehingga dalam waktu dekat impian warga Darmakradenan untuk menjadikan desa ini sebagai desa wisata akan segera terwujud 

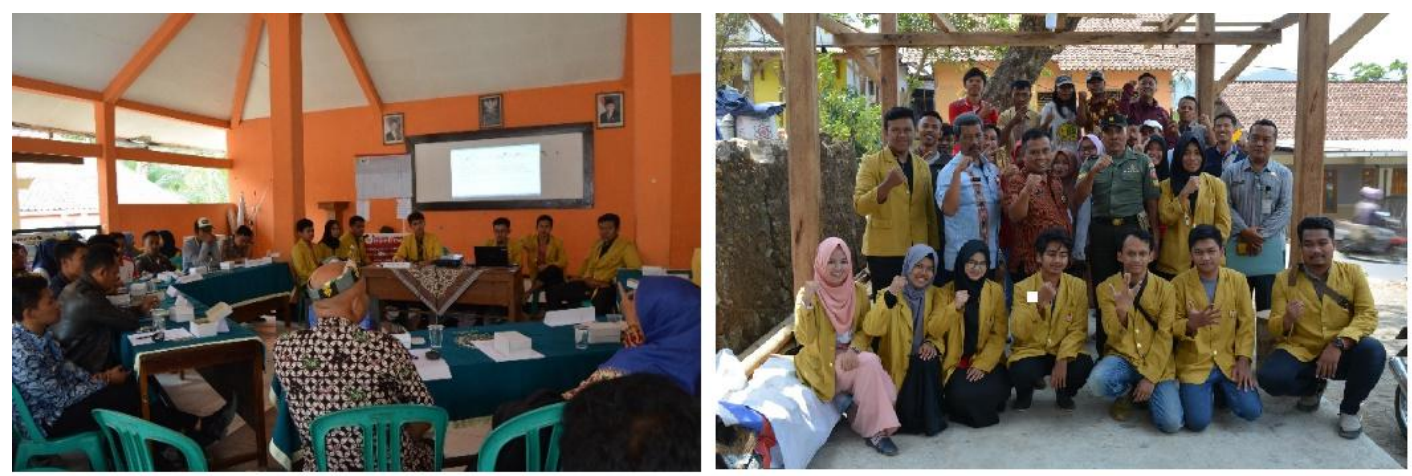

Gambar $k$ dan l. Sosialisasi potensi desa sebagai wanawisata berbasis agroforestri dan apikultur pada masyarakat dan pemangku kebijakan di Desa Darmakradenan dan Pemerintah Daerah Kab. Banyumas

d. Indikator keberhasilan dan Evaluasi Kegiatan.

Kegiatan KKN berjalan dengan baik, mahasiswa yang terlibat menjalankan perannya dengan maksimal, kelompok sasaran yaitu kelompok tani hutan Darma Jaya, Ibu-Ibu PKK, Masyarakat Desa Darmakradenan dan Siswa Sekolah Dasar. Terdapat peningkatan jumlah peternak lebah semula 25 menjadi 35 orang tergabung dalam kelompok, terdapat peningkatan jumlah koloni lebah, semula 200 kotak/rumah lebah menjadai 350 kotak lebah. Diharapkan peningkatan jumlah ini akan meningkatkan pula produksi madu yang dihasilkan. Evaluasi kegiatan KKN dilakukan dengan memberikan memberikan kuis terkait program kerja dan budiya lebah kepada mahasiswa peserta KKN, melaksanakan kunjungan lapangan untuk mengetahui sejauh mana program kerja yang telah disusun dapat berjalan dengan baik, dan memberikan penilaian terhadap kinerja mahasiswa peserta KKN, sekaligus dinilai oleh Kepala Desa dan rekan sesama mahasiswa.

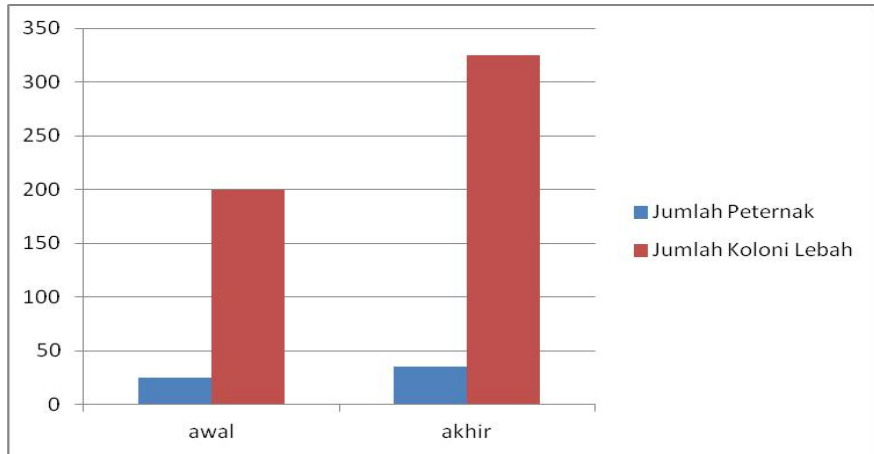

Grafik 1. Peningkatan jumlah anggota kelompok dan koloni lebah yang dimiliki.
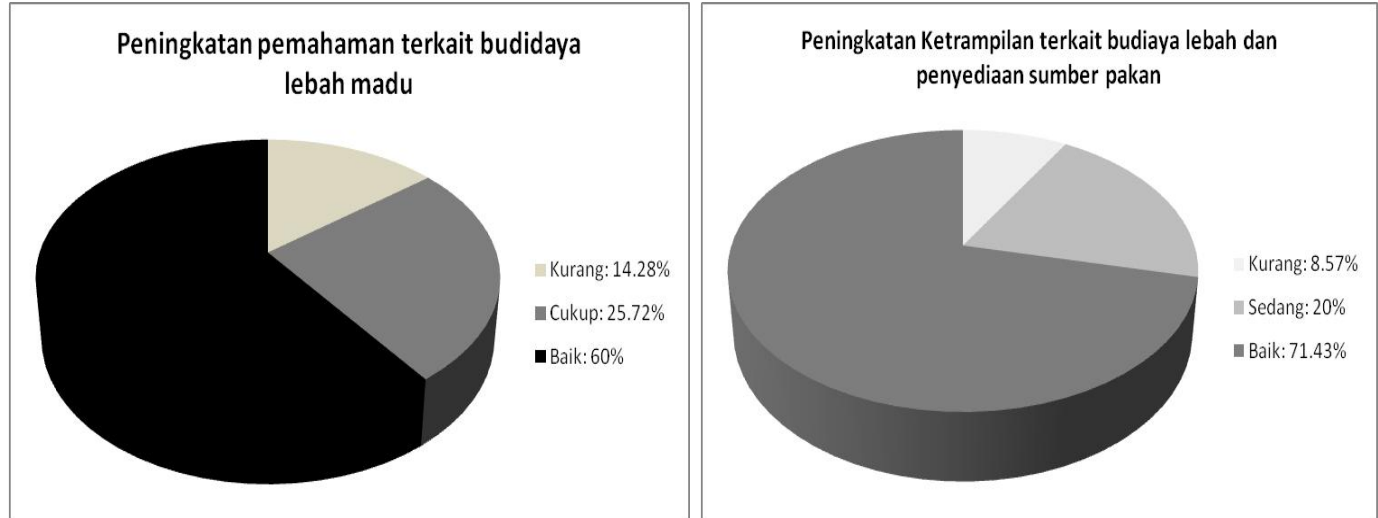

Grafik 2. Pemahaman kelompok tani terkait budidaya lebah

Grahik 3 Ketrampilan budidaya lebah dan penyediaan pakan 


\section{SIMPULAN}

Pelaksanaan KKN Tematik guna mendukung pengembangan budidaya lebah pada sistem pertanian agroforestri berjalan dengan baik, program kerja yang dilaksanakan berhasil meningkatkan jumlah anggota kelompok tani dan. menyiapkan roadmap pengembangan potensi wana wisata untuk ditindak lanjuti pemerintahan desa. Respon khalayak sasaran sangat antusias.

\section{UCAPAN TERIMAKSIH}

Penulis mengucapkan terima kasih kepada LPPM Universitas Jenderal Soedirman atas dukungan pendanaan kegiatan KKN Tematik dalam hibah Pengabdian BLU 2019, mahasiswa peserta KKN Darmakradenan, Anggota kelompok Tani Hutan Darmajaya, Seluruh Masyarakat dan Pemerintah Desa Darmakradenan atas kerjasamanya sehingga kegiatan dapat berjalan baik.

\section{DAFTAR PUSTAKA}

Bogdanov , S, Jurendic, T. Sieber R, GAllman P, 2008. Honey for Nutrition Food and Health, A Reveiew after Journal. American Journal of The College of Nutrition, 27: 677-689

Dinkominfo Kabupaten Banyumas. 2017. Infografis Desa Darmakradenan Kecamatan Ajibarang Kabupaten Banyumas. Buku Laporan Banyumas Dalam Angka

Kuntadi. (2003). Perlebahan di Indonesia. Jurnal Sylva Tropika Badan Penelitian dan Pengembangan Kehutanan.No 08 Vol 1: 25-32

Kuntadi, Y. A., \& A. Widiarti. (2012). Ujicoba Agroforestry MangiumJagung untuk Mendukung Budidaya Lebah Madu. Prosiding Seminar Nasional Agroforestri III. 29: 309-313.

Lamusa, A. 2010. Usaha Ternak Lebah Madu dan Faktor-Faktor yang Mempengaruhi Produksi Madu Di Desa Lolu Kabupaten Sigi Provinsi
Sulawesi Tengah. Jurnal Penelitian Agribisnis . 11(3) : 181-188.

Minarti, S. 2010. Ketersediaan Tepungsari dalam Menopang Perkembangan Anakan Lebah Madu Apis mellifera Di Areal Randu (Ceiba pentandra) dan Karet (Hevea brasilliensis). Jurnal Ternak Tropika. Malang.

Murtidjo B, 1991. Memelihara Lebah Madu. Yogyakarta: Kanasius.

Saepudin, R. 2013. Analisis Keberlanjutan Model Integrasi Lebah Dengan Kebun Kopi (SINKOLEMA) dalam Rangka Peningkatan Produksi Madu dan Biji Kopi. Jurnal SainPeternakan Indonesia. 8(1) : 1-16

Salmah, S. (1992). Lebah, pengembangan dan pelestariannya. (Pidato pengukuhan Guru Besar Tetap Ilmu Biologi). Fakultas Matematika dan Ilmu Pengetahuan Alam, Universitas Andalas.

Suharno dan Nazaruddin, 1994. Ternak Komersial. Penebar Swadaya. Jakarta 